\title{
基 \\ Agenesis of the seventh cervical vertebra with spinal cord compression in a goat
}

[Agenesia da sétima vertebra cervical com compressão da medula óssea em caprino]

"Comunicação Breve/Short Communication"

\author{
Lílian Gregory, Laura Cristina Sant'Anna Henriques, Juliana Silva Nogueira, \\ Camila Freitas Batista, Alice Maria Melville Paiva Della Libera, Silvana Maria Unruh, \\ Natalia Carrillo Gaeta*, Stefano Carlo Filippo Hagen
}

Departamento de Clínica Médica, Faculdade de Medicina Veterinária e Zootecnia, Universidade de São Paulo (USP), São Paulo-SP, Brasil.

*Autor para correspondência/Corresponding author: E-mail: natalia.gaeta@usp.br

\begin{abstract}
A 4-year-old male goat was presented to the Hospital of Bovines and Small Ruminants, University of São Paulo - Brazil, showing fasciculation in all limbs, ataxia progressing to paralysis and opisthotonos. After determination of the vital parameters and the specific evaluation of the nervous system, sensitivity in the region corresponding to the sixth cervical vertebrae (C6) and first thoracic vertebrae (T1) was observed on palpation. Further investigation using X-ray, myelography, and ultrasound revealed the decrease of the intervertebral space between C6 and T1, the presence of spondylosis and the absence of the seventh cervical vertebra (C7), which contained only the vertebral arch and local spinous process and the compression of the spinal cord. Goat congenital malformations are underdiagnosed, therefore, requires further discussion, and studies regarding the genetic variations.
\end{abstract}

Keywords: caprine; congenital malformation; small ruminant.

\section{Resumo}

Um caprino macho sem raça definida de quatro anos de idade foi recebido no Hospital de Bovinos e Pequenos Ruminantes da Universidade de São Paulo - Brasil, apresentando fasciculação em todos os membros, ataxia progredindo para paralisia e opistótono. Após a avaliação dos parâmetros vitais e o exame específico do sistema neurológico, detectou-se, por meio de palpação, sensibilidade na região correspondente a sexta vértebra cervical (C6) e a primeira vértebra torácica (T1). Uma investigação aprofundada por meio de raio-X, mielografia e ultrassom revelou a diminuição do espaço intervertebral em aproximadamente $30 \%$ próximo a região entre C6 e T1, presença de espondilose, ausência da sétima vertebra cervical (C7), além da observação somente dos arcos vertebrais, o processo espinhoso. Ademais, observou-se escoliose cervical e cifose toracolombar. Malformações congênitas em caprinos são pouco diagnosticadas e, portanto, requerem maiores discussões e estudos relacionados as variações genéticas.

Palavras-Chave: caprinos; malformações congênitas; pequenos ruminantes.

\section{Introduction}

According to Dennis and Leipold (1979), the incidence of abnormalities in lambs varies from $0.2 \%$ to $2 \%$. Congenital malformations are disorders present at birth that may have genetic and/or environmental causes. Errors during organogenesis may cause the partial or total absence of a structure or alter its normal configuration (Sadler, 2005). These effects may result in spinal malformations that may cause compression of the spinal canal and spinal cord, thus causing clinical symptoms that may be present at birth or appear only days later (Noden and De Lahunta 1990).

Although spinal malformations are well known, Castro et al. (2008) suggest that they are poorly explained. Perosomus elumbis is the term that describes a set of rare congenital anomalies, the most common of which is partial agenesis of 
the lumbosacral spinal cord and vertebrae. It also typically includes arthrogryposis of the hind limbs, characterized by ankylosis of the joints, with associated malformations of the musculature (Jones, 1999). Occasionally, this malformation is found in domestic animals, and its etiology is unknown (Jones, 1999; Jubb; Huxtable, 1993). The disease has been primarily described in cattle (Jones, 1999; Kim et al., 2007; Madarame et al., 1989) and sheep (Dennis, 1975a, 1975b, 1975c). In Brazil, there are rare reports of its occurrence, with cases reported in Holstein calves (Castro et al., 2003; Goizo et al., 2005) and sheep (Castro et al., 2008).

This report describes the clinical and pathological findings in a 04-month-old mongrel male goat that presented to the Hospital of Bovines and Small Ruminants, University of São Paulo Brazil, and provides important new information about this field.

\section{Material and Methods}

According to the owner, the animal was born in eutocia with another male kid without showing any apparent changes after birth. At approximately two months of age, the animal showed fasciculations in all legs and ataxia that progressed into a spastic paralysis. The owner did not observe any changes in the other goats born at the same time or in any other animals on the property. Vital parameters (rectal temperature, heart, and respiratory rate), the color of mucous, the degree of dehydration, and a specific neurological examination were performed according to Rosenberger (1993). Finally, a deep investigation using $\mathrm{x}$-ray, myelography, and ultrasonography was performed to characterize the clinical case better.

\section{Results}

The animal was in lateral recumbency with four stiff limbs that were unable to flex. Opisthotonos was also observed. Attempts to place the animal in sternal recumbency were unsuccessful (Figure 1). The animal had a normal appetite but reduced water intake. There were no reports of previous dewormings or vaccinations, but a fecal examination was negative. During clinical examination, the animal had a heart rate of $140 \mathrm{bpm}$, a rectal temperature of $38.9^{\circ} \mathrm{C}$ and two ruminal movements in five minutes. The mucous membranes and lymph nodes showed no changes. The packed cell volume and total protein were 39\% and $6.6 \mathrm{~g} / \mathrm{dL}$, respectively. No abnormal values for the vital functions were detected, and no hepatic or renal abnormalities were identified in the biochemical analysis. No abnormalities were identified in the cerebrospinal fluid. During the examination of the spine, the animal showed hypersensitivity upon palpation of the cervical and lumbar regions, and the cervical region was rigid and unable to flex.

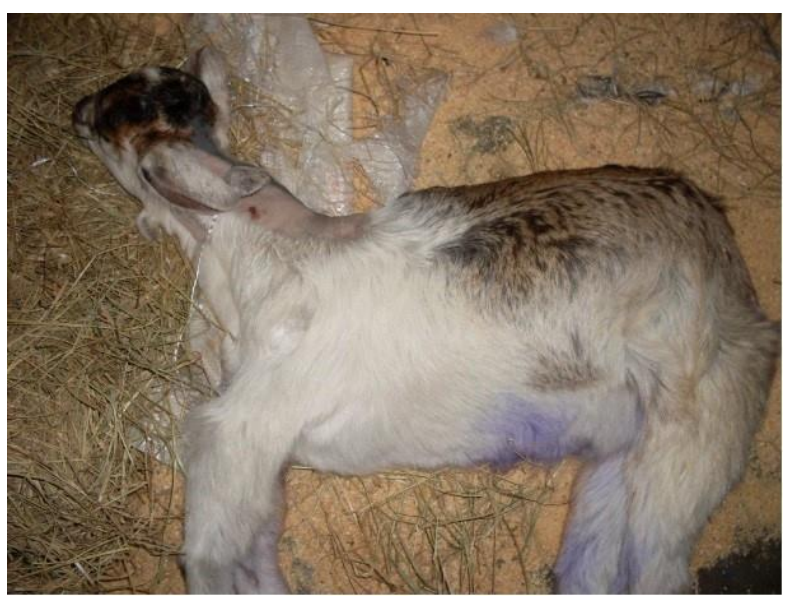

Figure 1. A 4-year-old male mongrel goat in permanent lateral recumbency showing no flexion of the four stiff limbs.

Radiographic examination showed the absence of the seventh cervical vertebra (C7), which contained only the vertebral arch and local spinous process. The approximation was evident in the vertebral faces between C6 and T1 (Figure 2). Additionally, C6 elevation and narrowing of the spinal canal (by approximately 30\%) next to the transition region between $\mathrm{C} 6$ and $\mathrm{T} 1$ were present. Radiographs also showed cervical scoliosis and thoracolumbar kyphosis. Furthermore, the bilateral incongruity of the hip joints was observed, with partial loss of the articular relationship (hip dysplasia) in the femoropatellar joint and the tibial side of the proximal patella (dislocation), causing muscle atrophy and diversion in the pelvic limbs. Contrast myelography confirmed the narrowing of the spinal cord in the $\mathrm{C} 7$ vertebral region. Ultrasonography of the cervical region was performed and confirmed the absence of $\mathrm{C} 7$ and the fusion of the vertebral C6 and T1 bodies. Although a congenital anomaly was not the primary initial diagnosis, the radiographic examination confirmed the agenesis and spinal cord compression. The animal was euthanized using intravenous xylazine $(0.3 \mathrm{mg} / \mathrm{kg})$, thiopental $(8 \mathrm{mg} / \mathrm{kg})$ and potassium chloride $(1 \mathrm{~mL} / \mathrm{kg})$. During a gross examination, the radiographic findings were confirmed; a cross- 
section of the spine revealed the absence of the seventh cervical vertebra, with a fusion of the sixth cervical vertebra to the first thoracic vertebra (Figure 3). Also, patellar dislocation with severe lateral deviation was observed, causing the pelvic and left hip dysplasia.

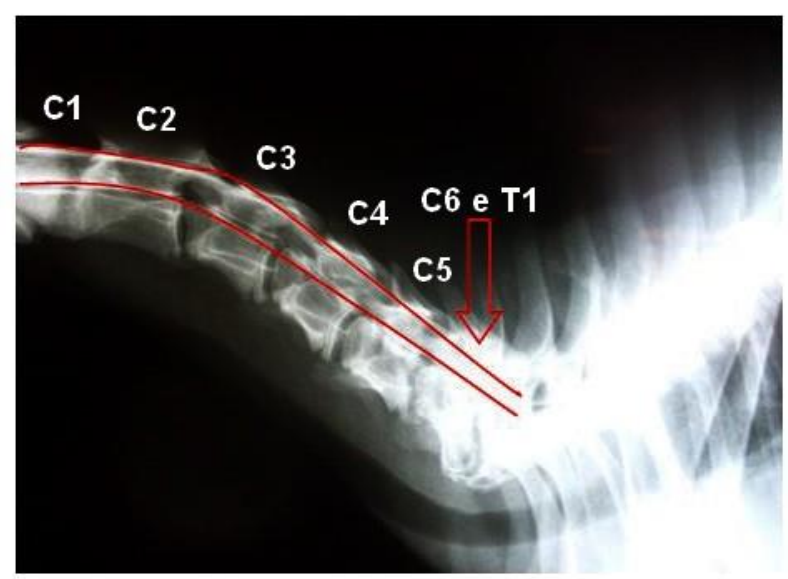

Figure 2. Radiography of the cervical-thoracic region from a 4-old-year male mongrel goat showing the agenesis of C7 and fusion of C6 and T1 (arrow).

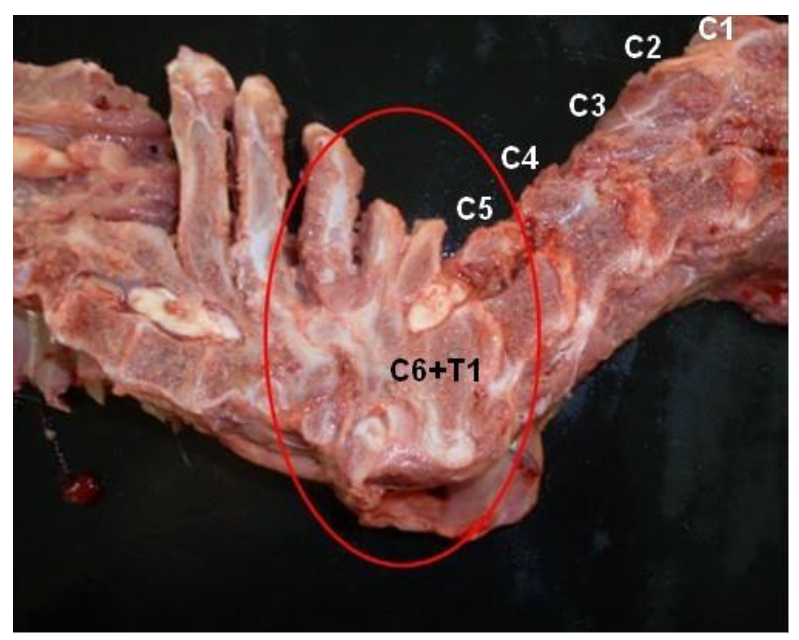

Figure 3. Macroscopic examination of the cervical-thoracic region during the necropsy of a 4-old-year male mongrel goat showing the agenesis of $\mathrm{C} 7$ and fusion of $\mathrm{C} 6$ and $\mathrm{T} 1$ (circle).

\section{Discussion}

A 4-year-old male mongrel goat was presented at the Hospital of Bovines and Small Ruminants, University of São Paulo showing fasciculation in all limbs, ataxia progressing to paralysis and opisthotonus. After the physical examination, a lesion was detected between the sixth cervical vertebrae (C6) and first thoracic vertebrae (T1). Many findings in the present study were similar to those reported by Castro et al. (2008), Gurlt (1877), and Jones (1999). Castro et al. (2008) reported the occurrence of Perosomus elumbis in a one-week-old mongrel female lamb referred to the Veterinary Hospital of the University of France. On inspection, the animal remained in sternal recumbency and was unable to ambulate. The absence of cutaneous sensation along the lower back, lack of muscle tone in the tail, and arthrogryposis of the hind limbs was observed. Radiographic examination showed an absence of the spine after the thirteenth thoracic vertebra (T13) and incomplete formation of the sacral vertebrae. The T13 vertebra was deformed, with a reduced size, and the adjacent ribs were malformed. During necropsy, the clinical and radiographic findings were confirmed, as in the presented case report. In addition, it was noted that the pelvis and hind limbs were attached to the body's anterior portion only by connective tissue, muscle, and atrophic skin. The spinal cord and spinal canal ended in the thoracic region (T13) corresponding to the location of the malformation, and the subsequent vertebral arches and the cauda equina were completely absent. In addition to arthrogryposis, atrophic malformations were observed in the pelvic bones, and the pubic bones were absent.

Jones (1999) has also reported Perosomus elumbis in a female Holstein calf referred to the School of Veterinary Medicine of the University of Pennsylvania. On necropsy, the head, neck, and forelimbs appeared normal. The hind limbs were severely misshapen, characterized by multiple angular limb deformities and abnormally small muscles. Radiographic examination and subsequent dissection revealed that this was due to a decreased number of vertebrae and the corresponding ribs. Radiographs revealed normal cervical vertebrae. The eighth and ninth thoracic vertebrae were short, and their dorsal spinous processes were fused. The 10th through the 13th vertebrae were individually indistinguishable and appeared as a dorsally arching bony mass.

Gurlt (1877) reported two cases of Perosomus elumbis in a study of skeletons. In the first case, he found that the lumbar vertebrae, sacrum, and coccygeal vertebrae were missing. A second had some missing lumbar vertebrae and an abnormally small sacrum.

\section{Conclusion}

Although the congenital malformation described in the present case report does not appear to match the classification of Perosomus elumbis, there are some similarities with the case presented. In both cases, the diagnosis was due to the absence 
of a vertebral body that was not diagnosed on presentation. Congenital malformations are underdiagnosed and, therefore, require further discussion and studies about the genetic variations.

\section{Conflict of interests}

Authors declare no conflict of interests.

\section{Acknowledgments}

Authors are thankful to the Department of Internal Medicine from School of Veterinary Medicine and Animal Sciences, University of São Paulo, Brazil, for all the support.

\section{References}

Castro, M.B.; Szabó, M.P.; Hokamura, H.K.; Romano, M.A. Perosomus elumbis in a Holstein calf in Brazil. Veterinary Record, 152(24):753, 2003.

Castro, M.B.; Szabó, M.P.J.; Moscardini, A.R.C.; Borges, J.R.J. Perosomus elumbis in sheep in Brazil. Ciência Rural. 38(1):262-265, 2008.

Dennis, S.M. Perinatal lamb mortality in Western Australia: 7. Congenital defects. Australian Veterinary Journal. 51(2):80-82, 1975a.

Dennis, S.M. Perosomus elumbis in sheep. Australian Veterinary Journal. 51(3): 135136, $1975 b$.

Dennis, S.M. Congenital defects of the nervous system of lambs. Australian Veterinary Journal. 51(8), 385-388, 1975c.
Dennis, S.M.; Leipold, H.W. Ovine congenital defects. Veterinary Bull. 49:233-239, 1979.

Goizo, P.F.I.; Di Santis, G.W.; Bandarra, E.P. Perosomus elumbis em bovino: relato de caso. Revista de Educação Continuada CRMVSP. 8:164-167, 2005.

Jones, C.J. Perosomus elumbis (vertebral agenesis and arthrogriposis) in a stillborn Holstein calf. Veterinary Pathology. 36:64-70, 1999.

Jubb, K.V.F.; Huxtable, C.R. Perosomus elumbis. In: Jubb, K.V.F.; Kennedy, P.C.; Palmer, N. Pathology of domestic animals, San Diego: Academic Press. 1993. P.276.

Kim, C.S.; Koh, P.O.; Cho, J.H.; Park, O.S.; Cho, K.W.; Kim, G.S.; Won, C.K. Sacrocaudal agenesis in a Korean native calf (Bos Taurus Coreanae). Journal of Veterinary Medicine Science. 69(6), 653-655, 2007.

Madarame, H.; Azuma, K.; Nozuki, H.; Konno, S. Perocormus associated with segmental aplasia of the cervical spinal cord in a Japanese shorthorn calf. Journal of Comparative Pathology. 101(2), 225-230. 1989.

Noden D.M.; De Lahunta A. 1990. Embriologia de los animales domesticos. Acribia, Zaragoza. 399p.

Sadler, T. W. Langman medical embryology. Rio de Janeiro: Guanabara Koogan, 2005, 384p. 